\title{
On the formation of diaplectic glass: Shock and thermal experiments with plagioclase of different chemical compositions
}

\author{
Jörg FRITZ (D) ${ }^{1,2 *}$, Vera ASSIS FERNANDES ${ }^{3,4}$, Ansgar GRESHAKE (D) ${ }^{3}$, Andreas HOLZWARTH ${ }^{5}$, \\ and Ute BÖTTGER ${ }^{6}$ \\ ${ }^{1}$ Saalbau Weltraum Projekt, Liebigstraße 6, 64646 Heppenheim, Germany \\ ${ }^{2}$ Zentrum für Rieskrater und Impaktforschung Nördlingen (ZERIN), Vordere Gerbergasse 3, 86720 Nördlingen, Germany \\ ${ }^{3}$ Museum für Naturkunde, Leibniz Institut für Biodiversität und Evolutionsforschung, Invalidenstraße 43, 10115 \\ Berlin, Germany \\ ${ }^{4}$ School of Earth and Environmental Science, University of Manchester, Oxford Road, Manchester M13 9PL, UK \\ ${ }^{5}$ Ernst Mach Institut für Kurzzeitdynamik, Fraunhofer Institut, Am Klingenberg 1, 79588 Efringen-Kirchen, Germany \\ ${ }^{6}$ Institut für Optische Sensoren Systeme, Deutsches Zentrum für Luft und Raumfahrt (DLR), Rutherfordstr. 2, 12489 \\ Berlin, Germany \\ *Corresponding author. E-mail: joerg.fritz@kino-heppenheim.de
}

(Received 24 April 2018; revision accepted 14 March 2019)

\begin{abstract}
This contribution addresses the role of chemical composition, pressure, temperature, and time during the shock transformation of plagioclase into diaplectic glass-i.e., maskelynite. Plagioclase of $\mathrm{An}_{50-57}$ and $\mathrm{An}_{94}$ was recovered as almost fully isotropic maskelynite from room temperature shock experiments at 28 and $24 \mathrm{GPa}$. The refractive index (RI) decreased to values of a quenched mineral glass for $\mathrm{An}_{50-57}$ plagioclase shocked to $45 \mathrm{GPa}$ and shows a maximum in $\mathrm{An}_{94}$ plagioclase shocked to $41.5 \mathrm{GPa}$. The $\mathrm{An}_{94}$ plagioclase experiments can serve as shock thermobarometer for lunar highland rocks and howardite, eucrite, and diogenite meteorites. Shock experiments at 28, 32, 36, and $45 \mathrm{GPa}$ and initial temperatures of 77 and $293 \mathrm{~K}$ on plagioclase $\left(\mathrm{An}_{50-57}\right)$ produced materials with identical optical and Raman spectroscopic properties. In the low temperature $(<540 \mathrm{~K})$ region, the formation of maskelynite is entirely controlled by shock pressure. The RI of maskelynite decreased in heating experiments of $5 \mathrm{~min}$ at temperatures of $>770 \mathrm{~K}$, thus, providing a conservative upper limit for the postshock temperature history of the rock. Although shock recovery experiments and static pressure experiments differ by nine orders of magnitude in typical time scale (microseconds versus hours), the amorphization of plagioclase occurs at similar pressure and temperature conditions with both methods. The experimental shock calibration of plagioclase can, together with other minerals, be used as shock thermobarometer for naturally shocked rocks.
\end{abstract}

\section{INTRODUCTION}

The term diaplectic glass (from the Greek word diaplesso $=$ to destroy by striking) was introduced by von Engelhardt et al. (1967) to describe an amorphous phase without vesicles and flow structures. It retains the grain boundaries, chemical composition, and zonation of the primary mineral. The density and refractive indices (RI) (a dimensionless number describing the speed of light in a material) of diaplectic glasses are lower than those of the primary crystal and higher than those of a quenched mineral glass (Bunch et al. 1967; von Engelhardt et al. 1967; Osinski et al. 2018). An amorphous phase forming pseudomorphs after plagioclase $\left(\mathrm{NaAlSi}_{3} \mathrm{O}_{8}-\mathrm{CaAl}_{2} \mathrm{Si}_{2} \mathrm{O}_{8}\right)$ was first described in the Shergotty achondrite by Tschermark (1872, 1883), and the author named this phase maskelynite, after the British mineralogist Mervyn Herbert Nevil Story Maskelyne. Milton and De Carli (1963) showed that maskelynite can be produced from plagioclase with bytownite composition $\left(\mathrm{An}_{80}\right)$ by shock recovery experiments at pressures of $25-35 \mathrm{GPa}$ and 
calculated postshock temperatures of $490-590 \mathrm{~K}$. Binns (1967) considered the lack of eutectic or eutectic-like melting phenomena with adjacent mafic minerals as an argument against a purely thermal origin of maskelynite. Instead, such diaplectic glasses form as a result of the material interacting with shock waves that are sufficiently intense to destroy the crystal lattice. After unloading the pressure, the material is left at a temperature below its melting point (von Engelhardt et al. 1967). Diaplectic glass is an umbrella term for shock amorphization including the open framework tectosilicates quartz and feldspar.

There is still a substantial discussion about the mechanism as well as the pressures and temperatures needed to form diaplectic glass during natural impact events, with pressures ranging between $<22$ and $>80 \mathrm{GPa}$ and temperatures varying by more than 1000 K (Stöffler et al. 1986; Sharp et al. 1999; Chen and El Goresy 2000; Kubo et al. 2010; El Goresy et al. 2013). A "hot melt" formation of diaplectic glasses assumes shock melting and subsequent quenching to a dense glass while still at elevated pressures. This process was proposed to explain the development of planar deformation features (PDF) in quartz (Grady 1980). Langenhorst (1994) and Stöffler and Langenhorst (1994) argued that above $35 \mathrm{GPa}$ the total quartz crystal is engulfed in molten PDF and that diaplectic glass represents a quenched high pressure melt. This model was later used to explain the formation of maskelynite (Chen and El Goresy 2000; El Goresy et al. 2013). A "cold" solid state amorphization and mechanical deformation of plagioclase was considered for the formation of maskelynite based on petrographic observation in meteorites and shock and heating experiments (e.g., Duke 1968; Hörz and Quaide 1973; Stöffler et al. 1986; Fritz et al. 2005a; Jaret et al. 2015). A solid state amorphization was observed after static pressure experiments at controlled temperatures of $293 \mathrm{~K}$ on Ca-rich $\left(\mathrm{An}_{96}\right)$ plagioclase (Williams and Jeanloz 1989) and on quartz (Hemley et al. 1988; Kingma et al. 1993) and during pre-cooled shock experiments at initial temperatures of $77 \mathrm{~K}$ on quartz (Fritz et al. 2011). Such a solid state amorphization is essentially consistent with the gradual formation of diaplectic glasses via mechanical disaggregation of the crystal lattice into domain sizes so small that they are beyond coherent X-ray diffraction (Hörz and Quaide 1973). In the present study, shock experiments on plagioclase of different chemical composition, and subjected to different pressures and initial temperatures, including annealing experiments on the resulting maskelynites are reported. These results are used together with shock and static pressure experiments literature data to discuss the influence of shock pressure, temperature, time, and composition on the formation of diaplectic glasses, in the present case maskelynite. This aids in resolving controversies on how to interpret the shock metamorphic record in meteorites (for a recent review, see Fritz et al. 2017).

\section{METHODS}

Samples of natural rocks containing plagioclase of different composition were experimentally shocked. Rock disks of $15 \mathrm{~mm}$ diameter and $0.6 \mathrm{~mm}$ thickness were cut from a troctolite hand specimen B59-36-A of the Gills Allard Economic Geology Collection, University of Georgia Museum of Natural History, Athens, Georgia, USA, and from a gabbro hand specimen from Grass Valley, California, USA, containing plagioclase with a chemical composition of $\mathrm{An}_{50-55}$ and $\mathrm{An}_{94}$, respectively. The disks were polished on both sides and placed into a high impedance container made from ARMCO iron. The rock samples and the ARMCO container for the shock experiments were prepared at the Museum für Naturkunde in Berlin, Germany (MfN). The shock recovery experiments using the reverberation technique were conducted at the Ernst Mach Institut für Kurzzeitdynamik (EMI) in Freiburg, Germany following the procedures described in Müller and Hornemann (1969), Meyer et al. (2011), and Fritz et al. (2011). Our shock experiments were conducted in the range of 20 $45 \mathrm{GPa}$ and at initial temperatures of $293 \mathrm{~K}$ (room temperature) to study the shock behavior of plagioclase with different chemical composition. Additional experiments at $77 \mathrm{~K}$, the boiling temperature of liquid nitrogen, were conducted to document the influence of temperature on the formation of maskelynite. Experimental details are given in Table 1, and the pressure in the sample is considered to be accurate to $4 \%$, i.e., $\pm 1.1-1.8 \mathrm{GPa}$ (Müller and Hornemann 1969).

After conducting the shock experiments, the ARMCO iron containers were machine-opened and the rock disks removed. From the polymineralic rock disks, plagioclase grains were handpicked. The RI of individual grains was determined at the MfN using the immersion method (Fritz et al. 2002, 2005a).

This was followed by heating experiments of individual maskelynite grains that were placed for $5 \mathrm{~min}$ into a preheated oven. The temperature of the oven was increased in $50 \mathrm{~K}$ temperature heating steps from 570 to 1170 K. Samples were inserted in the oven after it had acquired the new temperature, and the grains were kept at that temperature for $5 \mathrm{~min}$. The RI was determined after each temperature step.

The chemical composition of plagioclase was determined using thin sections of unshocked material and polished grain mounts of single grains for which 
Table 1. Conditions of the shock experiments with $0.6 \mathrm{~mm}$ thick and $15 \mathrm{~mm}$ diameter rock disks.

\begin{tabular}{lllllllll}
\hline RS & $P(\mathrm{GPa})$ & $T(\mathrm{~K})$ & $C(\mathrm{~mm})$ & $D(\mathrm{~mm})$ & Expl. & Init. $P(\mathrm{GPa})$ & $V\left(\mathrm{~km} \mathrm{~s}^{-1}\right)$ & $t(\mu \mathrm{s})$ \\
\hline $\operatorname{Tr}\left(\mathrm{An}_{50-57}\right)$ & 28 & 77 & 6.2 & 4 & $\mathrm{C} 4(64)$ & 33 & 1.62 & 0.53 \\
$\operatorname{Tr}$ & 28 & 293 & 6.2 & 4 & $\mathrm{C} 4(64)$ & 33 & 1.62 & 0.53 \\
$\mathrm{Tr}$ & 32 & 77 & 8.8 & 3 & $\mathrm{C} 4(64)$ & 47 & 2.16 & 0.1 \\
$\mathrm{Tr}$ & 32 & 293 & 8.8 & 3 & $\mathrm{C} 4(64)$ & 47 & 2.16 & 0.1 \\
$\mathrm{Tr}$ & 36 & 77 & 6.5 & 3 & $\mathrm{C} 4(64)$ & 47 & 2.16 & 0.2 \\
$\mathrm{Tr}$ & 45 & 77 & 6.3 & 3 & Comp. B (64) & 52 & 2.35 & 0.27 \\
$\mathrm{GV}\left(\mathrm{An}_{94}\right)$ & 20 & 293 & 5.0 & 4 & TNT & 30 & 1.55 & 0.83 \\
$\mathrm{GV}$ & 24 & 293 & 11.0 & 4 & C4 (64) & 33 & 1.62 & 0.43 \\
$\mathrm{GV}$ & 28 & 293 & 6.2 & 4 & $\mathrm{C} 4(64)$ & 33 & 1.62 & 0.53 \\
$\mathrm{GV}$ & 36 & 293 & 6.5 & 3 & C4 (64) & 47 & 2.16 & 0.2 \\
$\mathrm{GV}$ & 41.5 & 293 & 9.5 & 3 & Comp. B (64) & 52 & 2.35 & 0.16 \\
\hline
\end{tabular}

Type of rock sample (RS) being either Troctolite (Tr) or Grass Valley Anorthite (GV), shock pressure in the sample $(P)$, initial temperature of the experiment $(T)$, thickness of cover plate $(C)$, thickness of driver plate $(D)$, type of explosive (Expl.), initial pressure on top of the iron container (init. $P$ ), velocity of the driver plate $(V)$, and pulse length of shock compression $(t)$ for shock pressure $(P)$.

the RI has been previously determined. Quantitative mineral chemical analyses were obtained at the MfN with a JEOL JXA 8500F field emission cathode electron microprobe equipped with five wavelength-dispersive spectrometers. Minerals were analyzed with a $10-15 \mathrm{kV}$ accelerating voltage, a $15 \mathrm{nA}$ beam current, and a defocused $10 \mu \mathrm{m}$ diameter beam. Suitable glass and mineral standards certified by the Smithsonian Museum were used as reference samples for electron microprobe analysis (Jarosewich et al. 1980).

Raman spectra were obtained at the Deutsches Zentrum für Luft- und Raumfahrt (DLR), Berlin, Germany using a confocal Raman microscope WITec alpha $300 \mathrm{R}$ of the polished grain mounts. The samples were excited with a $532 \mathrm{~nm}$ Nd:YAG laser. The Raman scatter was collected using a long working distance $100 \times$ objective (NA 0.8). The spot size on the sample was smaller than $1.5 \mu \mathrm{m}$ and the laser power on the transparent single grains corresponded to $8 \mathrm{~mW}$. Selected spectra were recorded with lower laser power of 1 and $4 \mathrm{~mW}$ on the sample to ensure that the samples were not modified by the measurements.

\section{RESULTS}

\section{$\mathrm{An}_{\text {50-57 Plagioclase Shocked at Initial Temperatures of }}$ $77 \mathrm{~K}\left(-196^{\circ} \mathrm{C}\right)$ and $293 \mathrm{~K}\left(20^{\circ} \mathrm{C}\right)$}

Troctolite disks containing millimeter-size $\mathrm{An}_{50-57}$ plagioclase grains were experimentally shocked at initial temperatures of 293 and $77 \mathrm{~K}$ and at pressures of 28 and $32 \mathrm{GPa}$, covering the approximate pressure range for maskelynitization (Ostertag 1983; Stöffler et al. 1986; Heymann and Hörz 1990) (Table 1). Shock experiments at higher pressures of 36 and $45 \mathrm{GPa}$ were conducted only at $77 \mathrm{~K}$. Transmitted light microscopy with crossed polarizers on thin sections showed that plagioclase from the $28 \mathrm{GPa}$ experiments was almost fully isotropic with only few birefringent domains observable in polished grain mounts. All plagioclase from the 32, 36, and $45 \mathrm{GPa}$ shock experiments were completely isotropic.

The RI and chemical composition of the shocked plagioclase in the troctolite are plotted in Fig. 1. In accordance with microscopic observations, the data points for the $28 \mathrm{GPa}$ experiments conducted at initial temperatures of 77 and $293 \mathrm{~K}$ were transitional between the fields for fully and partly isotropic material. The $28 \mathrm{GPa}$ experiments were performed to obtain partly birefringent material, but only a few birefringent domains were observed in the recovered material. The material recovered from the $28 \mathrm{GPa}$ shock experiments at initial temperatures of 77 and $293 \mathrm{~K}$ displays identical optical properties and clusters around the $30 \mathrm{GPa}$ isobar of the calibration diagram (Fig. 1).

The data from the $32 \mathrm{GPa}$ experiments at 77 and $293 \mathrm{~K}$ display a similar trend. In the calibration diagram (Fig. 1), data fall along isobars indicating slightly (2-3 GPa) higher shock pressures. Maskelynite with identical optical properties was recovered from the $32 \mathrm{GPa}$ experiments conducted at initial temperatures of 77 and $293 \mathrm{~K}$. The $36 \mathrm{GPa}$ shock experiment at initial temperatures of $77 \mathrm{~K}$ produced maskelynite similar to that produced in the $32 \mathrm{GPa}$ experiments at 77 and $293 \mathrm{~K}$ with data points plotting between the 34 and $40 \mathrm{GPa}$ isobars in the calibration diagram (Fig. 1). The shock experiments at $45 \mathrm{GPa}$ and initial temperatures of $77 \mathrm{~K}$ produced material with optical properties similar to those of a thermal mineral glass. The $45 \mathrm{GPa}$ data in Fig. 1 show significantly less scatter than data from shock experiments between 28 and $36 \mathrm{GPa}$. 


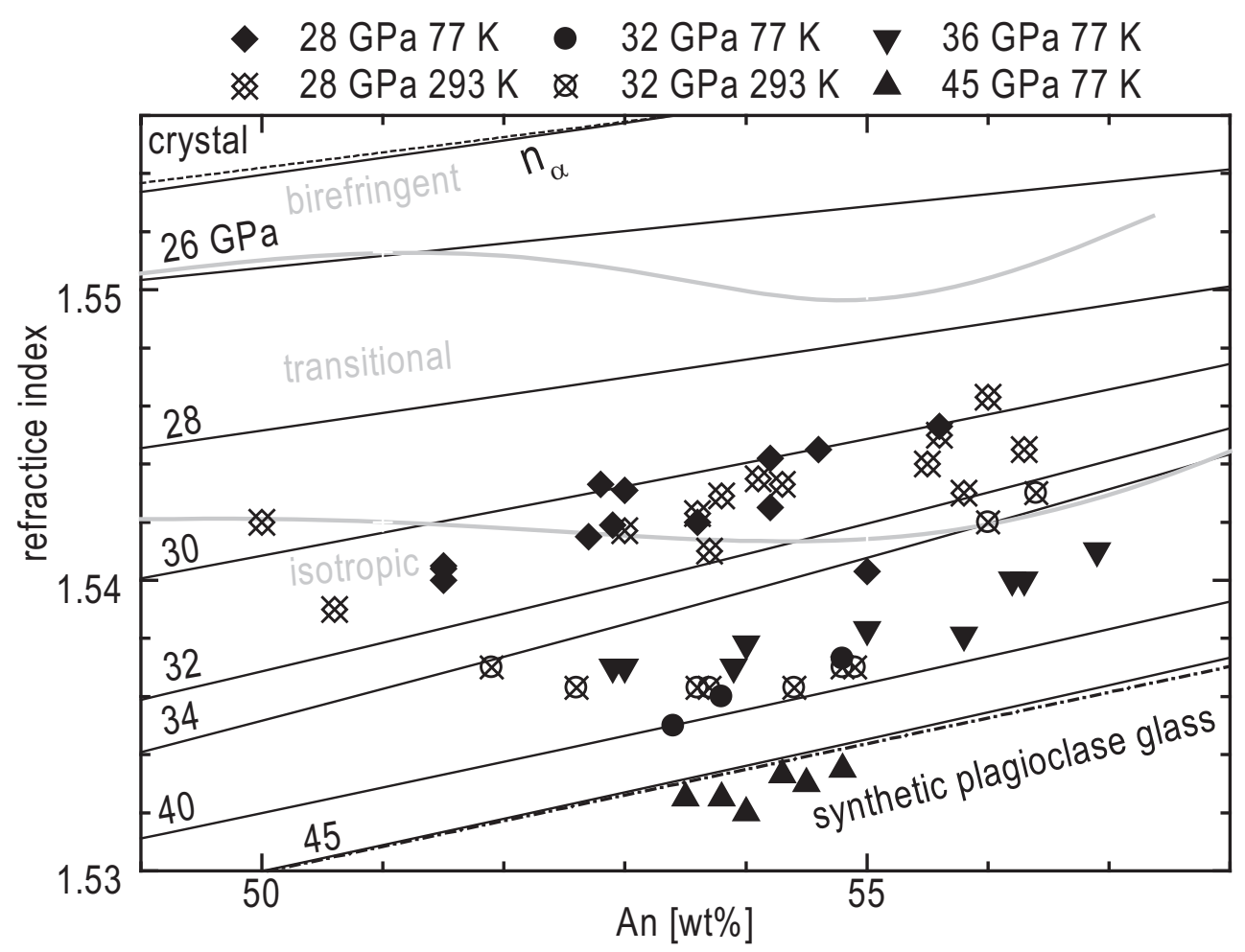

Fig. 1. Refractive index (RI) versus chemical composition (anorthite content $=$ An) of plagioclase samples experimentally shocked to different pressures and at different initial temperatures of the experimental setup. Refractive indices of plagioclase crystals (for $n_{\alpha}$ ) and their synthetic (thermal) glasses from Tröger (1982). Solid black lines represent isobars for shock pressures that produce from plagioclase materials with the according optical properties; i.e., showing the indicated RI and being either birefringent, partly birefringent, or fully isotropic. The gray lines separate the fields of birefringent and partly birefringent plagioclase from fully isotropic maskelynite (redrawn after Stöffler et al. 1986).

\section{An 94 Plagioclase Shocked at an Initial Temperature of $293 \mathrm{~K}\left(20^{\circ} \mathrm{C}\right)$}

The influence of the chemical composition on the formation of maskelynite is investigated by room temperature experiments using the Grass Valley gabbro that contains next to pyroxene a homogeneous, Ca-rich plagioclase of $\mathrm{An}_{94}$. Visual inspection of the unshocked, polished rock disks reveals millimeter-size grains of dark green pyroxene and up to centimeter-size white plagioclase, with both minerals displaying an intense luster. These whole rock disks were shocked to pressures between 20 and $41.5 \mathrm{GPa}$ and at initial temperatures of $293 \mathrm{~K}\left(20{ }^{\circ} \mathrm{C}\right)$. In the $20 \mathrm{GPa}$-shocked sample, both pyroxene and plagioclase are strongly fractured and the minerals appear milky, pale, and without luster. In contrast, plagioclase recovered from the 24, 28, 36 and $41.5 \mathrm{GPa}$ shock experiments appears more coherent, significantly less fractured, and of increasing transparency. Pyroxene appears highly fractured and without luster during visual inspection.

The RI of unshocked and shocked plagioclase $\mathrm{An}_{94}$ is shown in Fig. 2. The unshocked and the $20 \mathrm{GPa}$ shocked plagioclase grains are birefringent and both have an RI of 1.586 that is slightly higher than the RI of 1.584 for crystalline $A_{94}$ plagioclase as reported by Tröger (1982). At shock pressures of $24 \mathrm{GPa}$, plagioclase was almost fully transformed to isotropic maskelynite. In maskelynite formed at pressures of 24,32 , and $36 \mathrm{GPa}$, the RIs are $1.584,1.582$, and 1.576 , respectively. These RI values are within the range of an isochemical crystalline plagioclase (Fig. 2), and within the range of RI determined from lunar maskelynite $\left(\mathrm{An}_{84-96}\right)$ in Apollo 11 soil samples (von Engelhardt et al. 1970). The $41.5 \mathrm{GPa}$ shock experiment produced amorphous material with an RI between 1.586 and 1.590 , which is higher than the RI of the unshocked starting material (Fig. 2). For comparison, Fig. 2 displays literature data from Reynard et al. (1999) for synthetic anorthite glass $\left(\mathrm{An}_{100}\right)$ shocked to pressures of 17-41 GPa together with the RI of $\mathrm{An}_{94}$ maskelynite from the $1170 \mathrm{~K}$ heating experiment (see next paragraph).

\section{Heating Experiments with Maskelynite of Different Chemical Compositions}

Maskelynite produced in the $24 \mathrm{GPa}$ shock experiment from Ca-rich plagioclase $\left(\mathrm{An}_{94}\right)$ and in a 


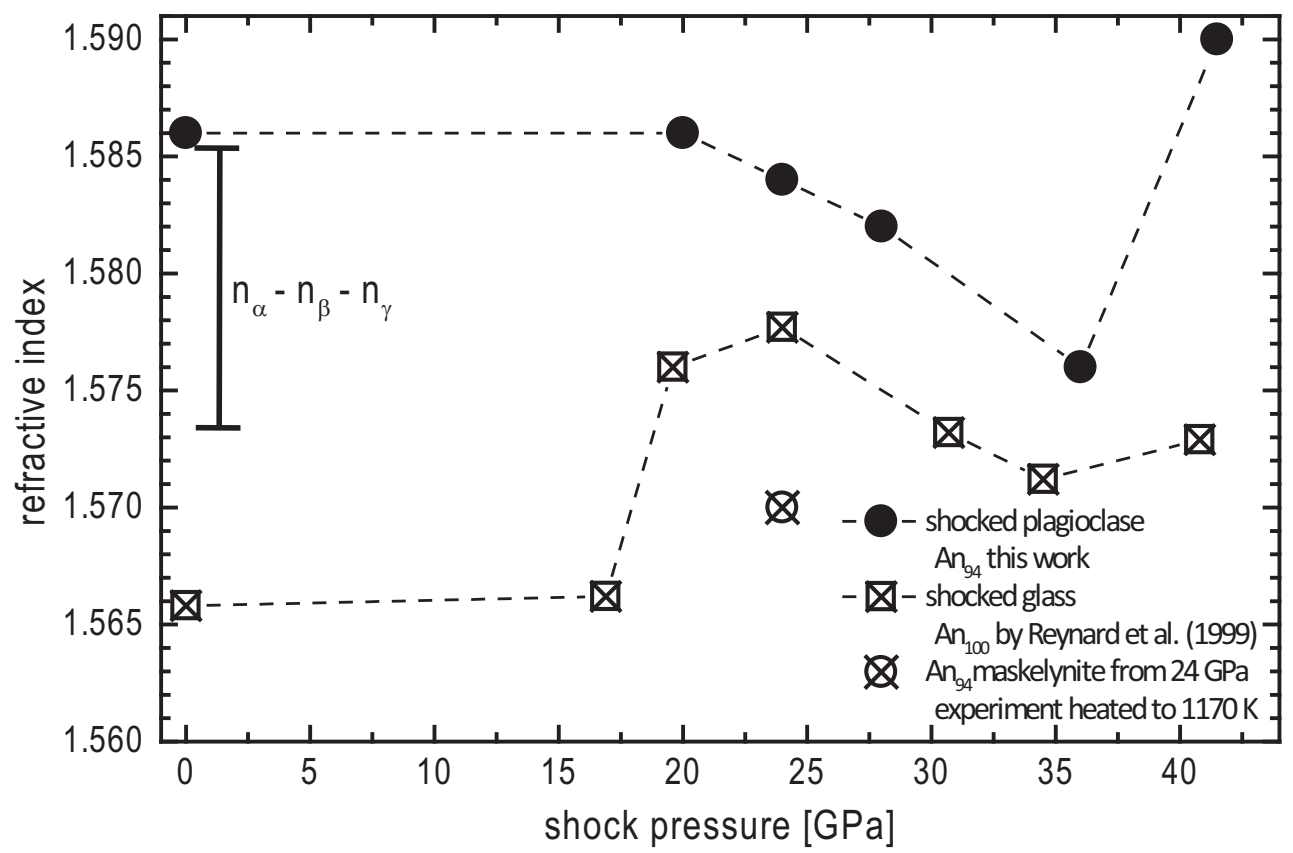

Fig. 2. Refractive index (RI) of experimentally shocked plagioclase ( $\mathrm{An}_{94}$ - this work) and synthetic glass $\left(\mathrm{An}_{100}-\mathrm{Reynard}\right.$ et al. 1999). Additionally displayed is the RI of a plagioclase shocked to $24 \mathrm{GPa}$ and then heated in an oven at temperatures of $1170 \mathrm{~K}$. It has an RI identical to those of an isochemical glass (Tröger 1982). The range of refractive indices $\left(n_{\alpha}, n_{\beta}, n_{\gamma}\right)$ for crystalline plagioclase with $\mathrm{An}_{94}$ as given by Tröger (1982) is indicated on the left.

$32 \mathrm{GPa}$ shock experiment from plagioclase of intermediate composition $\left(\mathrm{An}_{50-57}\right)$ were used in $50 \mathrm{~K}$ step heating experiments at temperatures from 570 to $1170 \mathrm{~K}$ (Fig. 3). Up to temperatures of $770 \mathrm{~K}$ the RI of the $\mathrm{An}_{94}$ sample remains unaffected. The RI slightly decreased after being exposed to $820 \mathrm{~K}$ for $5 \mathrm{~min}$, and it remained unchanged until $870 \mathrm{~K}$; it was then followed by a small decrease after being heated to temperatures of 920 and $1020 \mathrm{~K}$. Further increase in the temperatures to $1170 \mathrm{~K}$ finally produced a sample with an RI of 1.570 , equal to the RI of an isochemical thermal glass. For the relatively Na-rich $\mathrm{An}_{50-57}$ sample shocked to $32 \mathrm{GPa}$, the initial RI of 1.538 was unaffected up to $920 \mathrm{~K}$. At still higher temperatures, the $\mathrm{RI}$ of the $\mathrm{An}_{50-57}$ sample decreased in a similar fashion to that of the $\mathrm{An}_{94}$ sample (Fig. 3). At temperatures of $1170 \mathrm{~K}$, the $\mathrm{An}_{50-57}$ samples acquired an $\mathrm{RI}$ of 1.532 , the value of an isochemical thermal glass.

\section{Raman Spectroscopy on Plagioclase of Different Chemical Composition Shocked to Different Pressures}

Representative Raman spectra from plagioclase and maskelynite with $\mathrm{An}_{55-57}$ are displayed in Fig. 4. The unshocked sample shows spectra characteristic of plagioclase, including intense bands at 480 and $511 \mathrm{~cm}^{-1}$, and a relatively smaller band at $566 \mathrm{~cm}^{-1}$ (Mernagh 1991; Freeman et al. 2008). With increasing shock pressure the $566 \mathrm{~cm}^{-1}$ band increases relative to the 480 and $511 \mathrm{~cm}^{-1}$ bands, and these three bands form a broad hump. The $797 \mathrm{~cm}^{-1}$ band decreases and broadens and all bands below $410 \mathrm{~cm}^{-1}$ disappear. In addition, a prominent broad hump between 900 and $1150 \mathrm{~cm}^{-1}$ develops. In a few locations of the $28 \mathrm{GPa}$ samples shocked at temperatures of 77 and $293 \mathrm{~K}$, the collected spectra acquire narrow bands at 486 and $511 \mathrm{~cm}^{-1}$ on the broad hump, thus indicating a few regions with incomplete amorphization. The typical Raman spectra of maskelynite are characterized by two broad humps between 450 to 600 and 950 to $1150 \mathrm{~cm}^{-1}$. With increasing shock pressure and decreasing RI, the shape of the broad hump between 450 and $600 \mathrm{~cm}^{-1}$ changes as the relative contribution of the $570 \mathrm{~cm}^{-1}$ band decreases (Fig. 4).

Raman spectra from plagioclase and maskelynite with $\mathrm{An}_{94}$ reveal a similar evolution (Fig. 5). Unshocked plagioclase and plagioclase shocked to $20 \mathrm{GPa}$ show nearly identical Raman spectra with distinct bands characteristic of plagioclase. The $24 \mathrm{GPa}$ sample displays two broad humps between 450 to 600 and 950 to $1150 \mathrm{~cm}^{-1}$ indicative of maskelynite. Raman spectra from the $\mathrm{An}_{94}$ samples shocked to $41.5 \mathrm{GPa}$ display 570/ $500 \mathrm{~cm}^{-1}$ band intensity ratio (the relative contribution of the $570 \mathrm{~cm}^{-1}$ band) similar to that from spectra of isochemical maskelynite produced by lower shock pressures (Fig. 5). Notably, $\mathrm{An}_{94}$ maskelynite produced in the $41.5 \mathrm{GPa}$ shock experiment has an RI substantially 


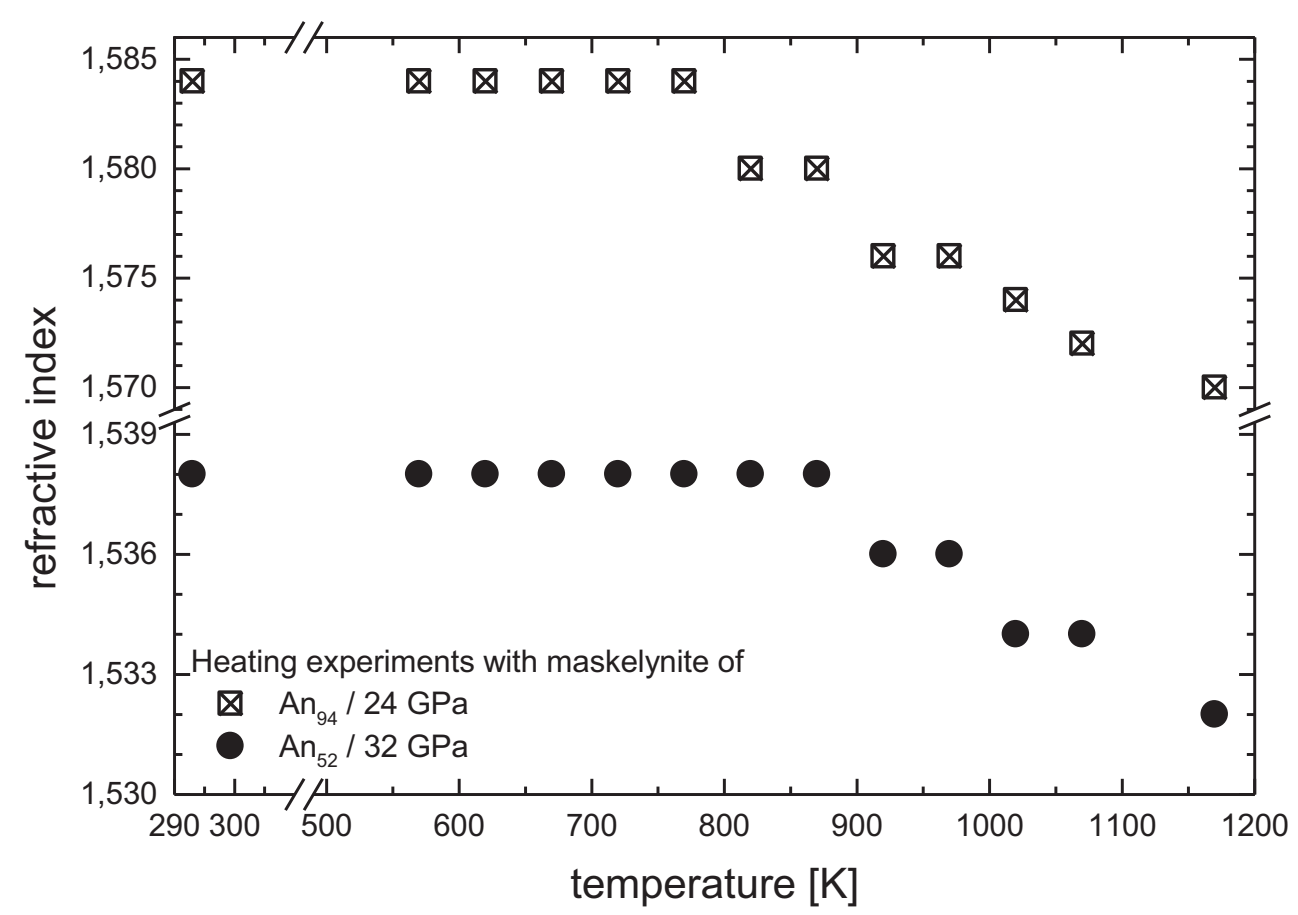

Fig. 3. Refractive index versus temperature determined with heating experiments using the shock experimentally produced maskelynite.

higher than that of maskelynite produced at lower shock pressures, and higher than that of the starting material. For comparison, the Raman spectra of maskelynite with different chemical composition and maskelynite thermally annealed at temperatures of $1173 \mathrm{~K}\left(900{ }^{\circ} \mathrm{C}\right)$ for $5 \mathrm{~min}$ are displayed in Fig. 6 . The position of the $950-1150 \mathrm{~cm}^{-1}$ hump depends on the chemical composition of maskelynite and the maximum shifts from $1100 \mathrm{~cm}^{-1}$ in Na-rich maskelynite to $\sim 980 \mathrm{~cm}^{-1}$ in Ca-rich maskelynite. With increasing An content of the maskelynite, the $570 / 500 \mathrm{~cm}^{-1}$ band intensity ratio in the Raman spectra increases. In addition, the $570 / 500 \mathrm{~cm}^{-1}$ band intensity ratio decreases with decreasing RI; i.e., the $570 / 500 \mathrm{~cm}^{-1}$ ratio decreases from spectra obtained from the $28 \mathrm{GPa}$ shock-produced maskelynite $\left[\mathrm{An}_{50-57}\right.$ and $\left.\mathrm{An}_{94}\right]$ to those in spectra from maskelynite grains exposed to temperatures of $1170 \mathrm{~K}$ for $5 \mathrm{~min}$, as well as in the $\mathrm{An}_{50-57}$ maskelynite recovered from the $45 \mathrm{GPa}$ experiments. The Raman spectra from maskelynite provide information on the chemical composition and the $\mathrm{RI}$ and, thus, density of the amorphous material.

\section{DISCUSSION}

\section{Shock Formation of Maskelynite}

The observations described above on the experimentally produced maskelynite provide new information on the effect(s) of: (1) temperature during shock compression, (2) plagioclase composition with solidus and liquidus temperatures increasing from 1391 to $1826 \mathrm{~K}$ along the albite-anorthite solid solution series, and (3) postshock temperature on the annealing of maskelynite.

1. If plagioclase were to transform into maskelynite from a hot shock melt that rapidly quenched during decompression (Chen and El Goresy 2000; El Goresy et al. 2013), the following would be expected: Compared to room temperature (293 K) experiments, higher shock pressures will be required in much colder $(77 \mathrm{~K})$ experiments to eventually reach the melting temperature of plagioclase. However, materials produced at identical shock pressures but temperatures of 77 and $293 \mathrm{~K}$ have identical RI and Raman spectroscopic properties (Figs. 1 and 4). These results are equivalent to experimentally shocked quartz single crystals that resulted in identical shock deformation effects at any given pressure, at variable initial temperatures of 77 and $548 \mathrm{~K}$ (Fritz et al. 2011). Thus, the formation of diaplectic glasses from both quartz (Fritz et al. 2011) and plagioclase (this work) at low temperatures (initial temperatures of 77-293 K for plagioclase and $77-548 \mathrm{~K}$ for quartz) is controlled by shock pressure only and is independent of temperature variations. This together with the 


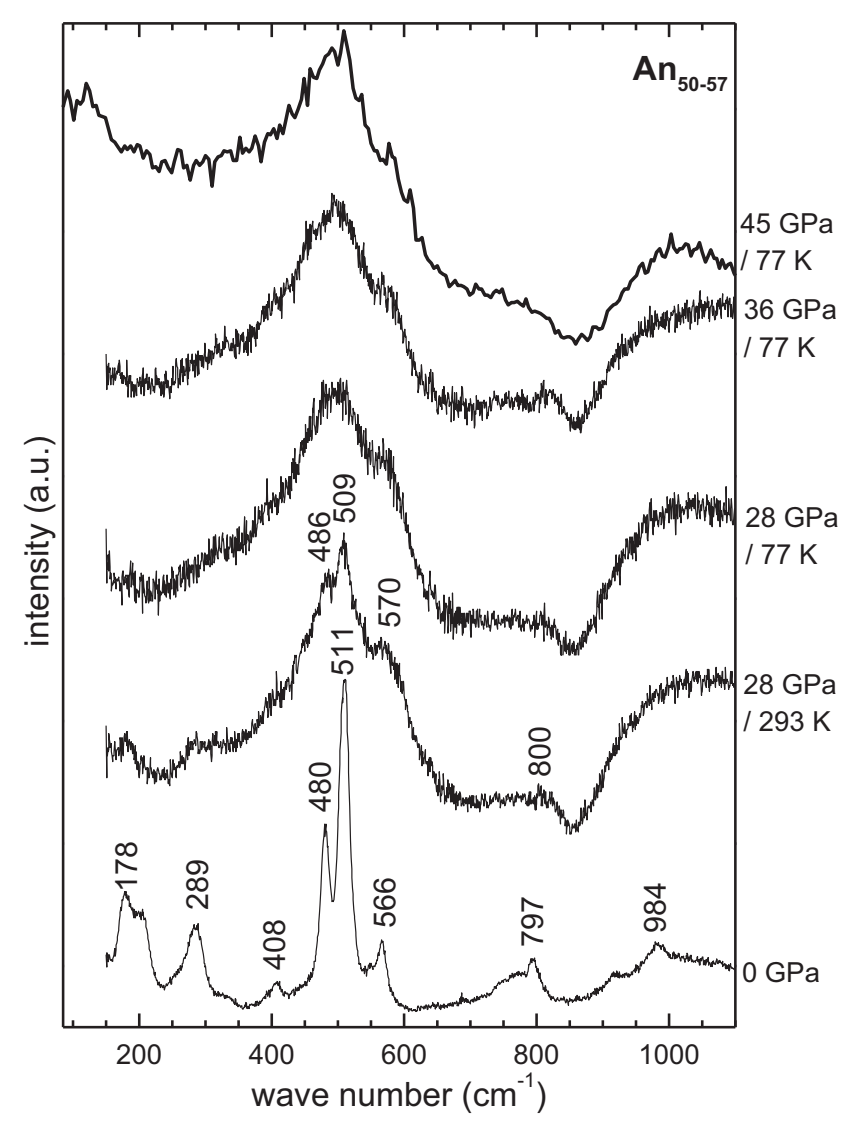

Fig. 4. Raman spectra of plagioclase with intermedium chemical composition $\left(\mathrm{An}_{50-57}\right)$ shocked to different pressures and at different initial temperatures. Displayed are two types of spectra, each observed in samples from the $28 \mathrm{GPa}$ experiments at 77 and at $293 \mathrm{~K}$. Raman spectra from the $32 \mathrm{GPa}$ samples (not shown) are very similar to the displayed spectra from the $36 \mathrm{GPa}$ sample, and both samples have similar RI (see Fig. 1).

observation that plagioclase gradually transforms into maskelynite (Hörz and Quaide 1973) excludes diaplectic glass formation by thermal melting and advocates for a solid state amorphization. In static experiments, albitic plagioclase remains amorphous following decompression from pressures of $37 \mathrm{GPa}$ at $440 \mathrm{~K}$ and from pressures of $31 \mathrm{GPa}$ at $540 \mathrm{~K}$ (Tomioka et al. 2010). This indicates that plagioclase is more sensitive to elevated temperatures than quartz; i.e., $>440 \mathrm{~K}$ for plagioclase versus $>548 \mathrm{~K}$ for quartz.

2. Compared to $\mathrm{An}_{50-57}$ plagioclase, the more Ca-rich $\mathrm{An}_{94}$ plagioclase has higher melting temperatures; i.e., at atmospheric pressure, the solidus of $\mathrm{An}_{50-57}$ and $\mathrm{An}_{94}$ is at 1500 and $1770 \mathrm{~K}$, respectively. Consequently, it could be predicted that $\mathrm{Ca}$-rich plagioclase should require higher shock pressures to melt during compression. However, consistent with

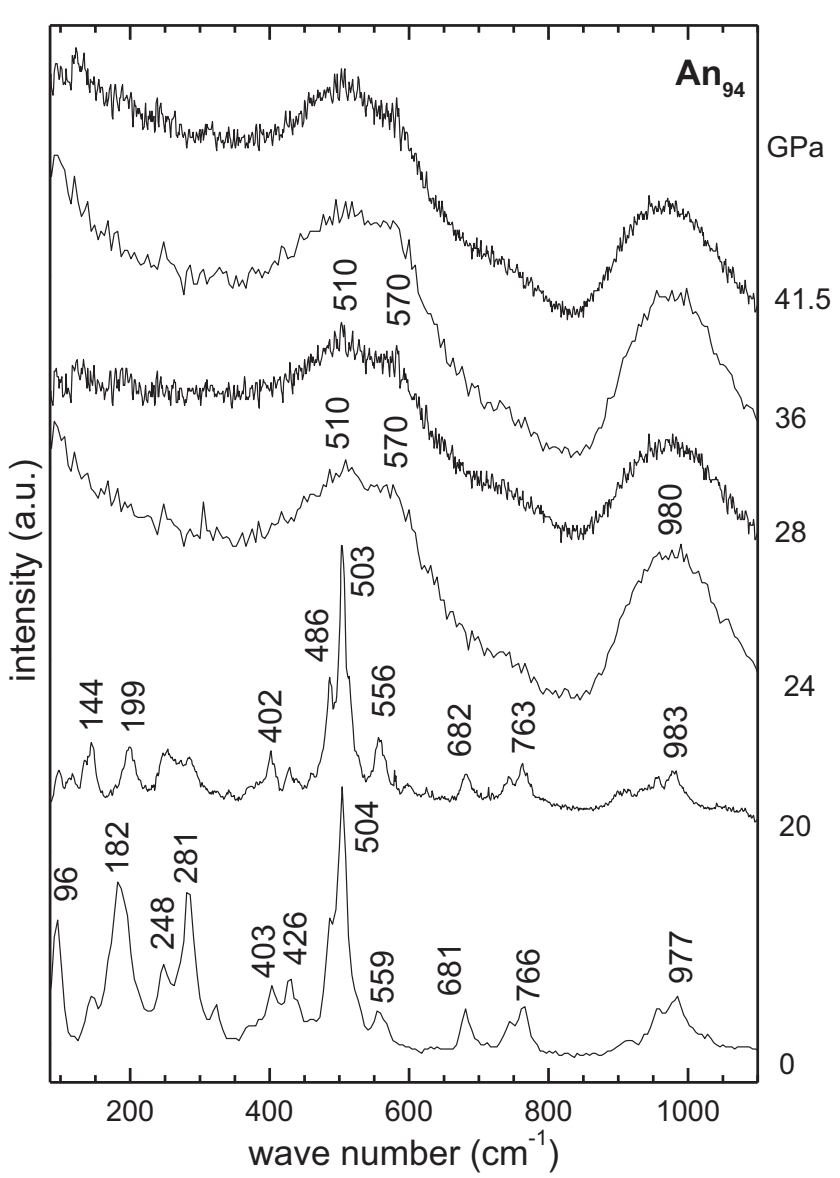

Fig. 5. Raman spectra of Ca-rich feldspar $\left(\mathrm{An}_{94}\right)$ shocked to different pressures at initial temperatures of $293 \mathrm{~K}$.

shock and static experiments (Ostertag 1983; Heymann and Hörz 1990; Daniel et al. 1997; Kubo et al. 2010; Johnson 2012), the opposite is observed, and the threshold pressure for the transformation decreases with increasing An-content (Fig. 7; Table 2). This trend can be explained by a pressureinduced failure of the plagioclase crystal lattice, and correlates with stronger $\mathrm{Si}-\mathrm{O}$ bounds being replaced by weaker Al-O bounds toward An-rich compositions along the albite $(\mathrm{Si} / \mathrm{Al}=3 / 1)$ to anorthite $(\mathrm{Si} / \mathrm{Al}=1 / 1)$ solid solution series. Compared to Na-rich plagioclase in Martian meteorites or ordinary chondrites $\left(\mathrm{An}_{<75}\right)$, the Ca-rich maskelynite in lunar and howardite, eucrite, and diogenite meteorites (e.g., $\mathrm{An}_{>75}$ ) form at lower pressures and, thus can be associated with olivine and pyroxenes that display a lower degree of shock deformation effects.

3. The annealing experiments of maskelynite provide temperature limits for the postshock thermal history of a specimen at zero pressure. At atmospheric pressures and residing at temperatures of 770 and 


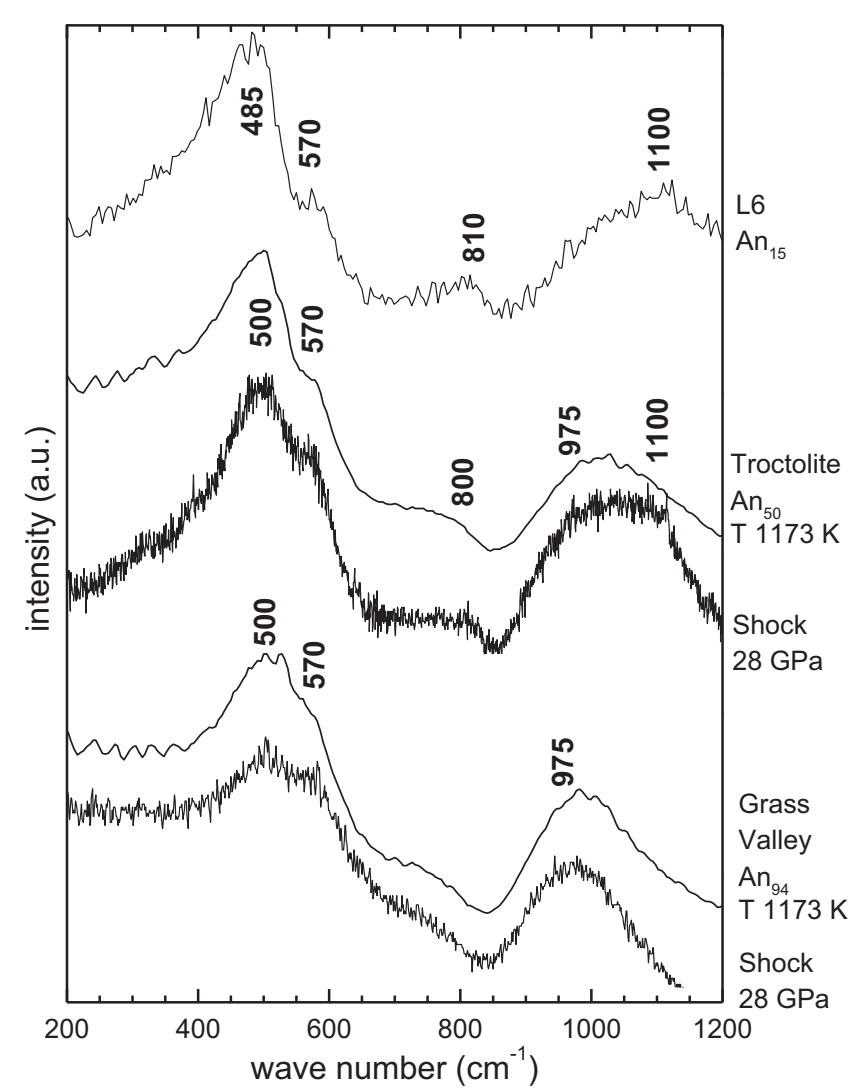

Fig. 6. Raman spectra of maskelynite with different chemical composition. The Grass Valley gabbro $\left(\mathrm{An}_{94}\right)$ and a troctolite $\left(\mathrm{An}_{50-57}\right)$ were experimentally shocked to $28 \mathrm{GPa}$. Raman spectra for these grains exposed for 5 min to temperatures of $>1173 \mathrm{~K}\left(900^{\circ} \mathrm{C}\right)$ are shown in addition. The L6 chondrite $\left(\mathrm{An}_{15}\right)$ was naturally shocked. Note the variations in the $570 /$ $500 \mathrm{~cm}^{-1}$ band intensity ratio and the position of the broad hump between 900 and $1150 \mathrm{~cm}^{-1}$.

$900 \mathrm{~K}$ for $5 \mathrm{~min}$ at each temperature step, the RI of maskelynite starts to decrease (Fig. 2). The duration of our heating experiments is rather short compared with the cooling times in a natural environment, thus providing conservative upper limits for the thermal history of rocks containing maskelynite with the highest RI. In comparison, Duke (1968) used longer heating experiments on maskelynite from the Shergotty meteorite to show that it did not reach temperatures of $670 \mathrm{~K}$ following the shock event. Exposing maskelynite to temperatures of more than $1170 \mathrm{~K}$ for several hours to days eventually results in recrystallization to plagioclase (Ostertag and Stöffler 1982). The differences between the recrystallization of almost fully isotropic maskelynite and the crystallization of a thermal mineral glass are discussed by Arndt et al. (1982), indicating that maskelynite with high RI could retain a "memory" of the original crystal and, thus differs from a quenched glass. The observed annealing behavior documents the gradual transition of plagioclase to maskelynite and thus supports a solid state transformation process. The effect of shock pressure and postshock temperature on the RI of maskelynite will be discussed in the following section.

The experimental data show that the shock formation of maskelynite is a function mainly of chemical composition and pressure and can occur at rather low temperatures during shock compression and decompression.

\section{Formation of Maskelynite with High and Low RI}

This section discusses the effect of temperature and shock pressure on the RI of maskelynite by comparing the results of shock and thermal experiments (Figs. 1-3). Maskelynite with an RI close to the value of an isochemical thermal glass can be produced by increasing shock pressures to $\sim 45 \mathrm{GPa}$ (Fig. 1) or by heating maskelynite with a relatively high RI produced from plagioclase shocked to lower pressures - e.g., to pressures in the range of 25-35 GPa (Figs. 1-3). Reynard et al. (1999) reported that the RI of the shock densified glass increases with a maximum density and an RI of 1.577 at $25 \mathrm{GPa}$ (Fig. 2). At higher shock pressures, the recovered glass has a significantly lower RI value of 1.571 approaching the values of an isochemical thermal glass. Reynard et al. (1999) interpreted these experimental results as shock densification up to pressures of $25 \mathrm{GPa}$. These authors assumed that with increasing shock pressure, the higher postshock temperature causes thermal relaxation of the decompressed material. However, the experimental data presented here are somewhat inconsistent with the formation of low RI maskelynite only by postshock thermal relaxation of high RI maskelynite:

1. The $41.5 \mathrm{GPa}$ shock experiment on $\mathrm{An}_{94}$ plagioclase resulted in maskelynite with an RI of 1.590 that is higher than those for unshocked plagioclase and maskelynite produced at shock pressures of $36 \mathrm{GPa}$ (Fig. 2). Amorphous plagioclase $\left(\mathrm{An}_{96}\right)$ with a very high RI of 1.62 was previously reported from static pressure experiments at temperatures of $293 \mathrm{~K}$ (Williams and Jeanloz 1989). Notably, Reynard et al. (1999) also recovered shocked synthetic glass $\left(\mathrm{An}_{100}\right)$ with an RI that was slightly higher in the $41 \mathrm{GPa}$ compared with the $35 \mathrm{GPa}$ shock experiment (Fig. 2). These observations are inconsistent with a postshock temperature-induced reduction in the RI.

2. The $32 \mathrm{GPa}$ shock experiments at 77 and $293 \mathrm{~K}$ produced $\mathrm{An}_{50-57}$ maskelynite with identical optical properties and RI values and these RI values are 


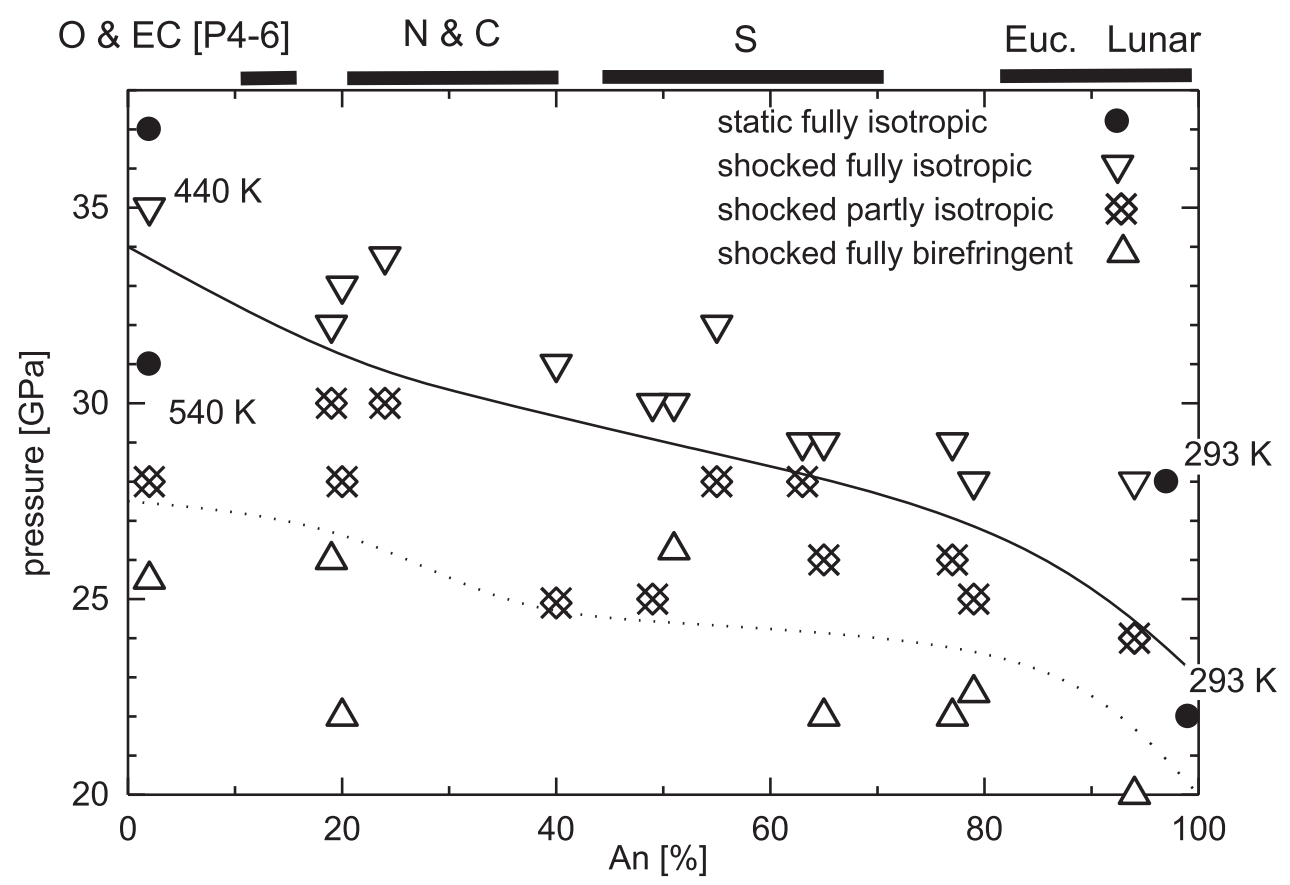

Fig. 7. Pressure versus anorthite content [An] for experimentally pressurized plagioclase. References are given in Table 2. Displayed are data from shock experiments conducted at initial temperatures of $293 \mathrm{~K}$. The dotted and solid lines indicate the shock pressures above which crystalline plagioclase grains (birefingent) of a given chemical composition are transformed into grains composed of crystalline and amorphous regions (partly isotropic) and grains completely transformed into amorphous maskelynite (fully isotropic). The solid line indicating the minimum shock pressure to form $\mathrm{An}_{94} \mathrm{maskelynite}$ approaches $24 \mathrm{GPa}$ as this shock experiment produced almost fully isotropic material (this work). For static pressure experiments, the temperatures during maximum compression are shown in the graph, and all displayed data points represent isotropic maskelynite. Different pressure values for the armorphization of plagioclase with $\mathrm{An}_{96}$ and $\mathrm{An}_{100}$ recovered from static pressure experiments were reported by Williams and Jeanloz (1989) and Daniel et al. (1997), respectively. Not included in the graph is the partly isotropic $\mathrm{An}_{96}$ maskelynite recovered from $22 \mathrm{GPa}$ experiments by Wiliams and Jeanloz (1989). The typical composition of plagioclase in different types of meteorites is indicated for lunar rocks (Moon), eucrites (Vesta?), the shergottites, chassignites, and naklites (Mars), as well as for equilibrated ordinary and enstatite chondrites (main belt asteroids). O \& EC (P 4-6) = ordinary and enstatite chondrites of petrological type 4-6 (Kovach and Jones 2010); N \& $\mathrm{C}=$ Naklites and Chassignites; $\mathrm{S}=$ Shergottites (Fritz et al. 2005a, 2005b); Euk = Eukrites (Mayne et al. 2009); Lunar (Wieczorek et al. 2006).

lower than those of $\mathrm{An}_{50-57}$ maskelynite from the $28 \mathrm{GPa}$ experiments at 77 and $293 \mathrm{~K}$. This suggests that the lower RI of the $32 \mathrm{GPa}$ maskelynite compared with the $28 \mathrm{GPa}$ maskelynite is related to pressure and not to temperature.

The formation of maskelynite requires shock pressures above the amorphization pressure of plagioclase with given composition. Maskelynite with high and low RI can be produced by shock pressure only. The RI of shock-produced maskelynite is sensitive to postshock thermal disturbances and thus provides an upper limit for the temperature of the rock after decompression (Fig. 3) (Duke 1968; Fritz et al. 2005b). In a naturally shocked rock, the shock pressures deduced from the RI of maskelynite can be compared to the degree of shock metamorphic overprint in olivine or pyroxene; i.e., compared to shock barometer that are less sensitive to postshock thermal disturbances.

\section{Comparison of Shock and Static Pressure Experiments}

To date, most research groups working on shock metamorphism presume substantial differences between static and shock experiments (e.g., Stöffler and Langenhorst 1994; Sharp and De Carli 2006; Gillet et al. 2007). Shock and static experiments differ in time scales of compression and decompression, and may also differ in temperature during compression, including hydrostatic (no friction or internal stress) and nonhydrostatic (friction or oriented stress) conditions. Tomioka et al. (2010) and Kubo et al. (2010) concluded that amorphization of plagioclase occurs at significantly lower pressures $(>10 \mathrm{GPa})$ in static compared to shock experiments. However, the present observations and literature data suggest that in both experimental settings the amorphization of plagioclase occurs at similar pressure and temperature conditions (Fig. 7; Table 2). 
Table 2. Compilation of the shock and static pressure experiments on plagioclase with different chemical composition presented in Fig. 8.

\begin{tabular}{|c|c|c|c|}
\hline $\begin{array}{l}\text { Chemical } \\
\text { composition }\end{array}$ & $\begin{array}{l}\text { Temperature } \\
(\mathrm{K})\end{array}$ & $\begin{array}{l}\text { Type of } \\
\text { experiment }\end{array}$ & References \\
\hline $\mathrm{An}_{02}$ & 293 & Shock & $\begin{array}{c}\text { Johnson and } \\
\text { Hörz (2003) }\end{array}$ \\
\hline $\mathrm{An}_{19}$ & & & $\begin{array}{l}\text { Heymann and } \\
\text { Hörz (1990) }\end{array}$ \\
\hline $\mathrm{An}_{20}$ & & & Ostertag (1983) \\
\hline $\mathrm{An}_{24}$ & & & $\begin{array}{l}\text { Stöffler et al. } \\
\text { (1986) }\end{array}$ \\
\hline $\mathrm{An}_{40}$ & & & Johnson (2012) \\
\hline $\mathrm{An}_{49}$ & & & $\begin{array}{c}\text { Heymann and } \\
\text { Hörz (1990) }\end{array}$ \\
\hline $\mathrm{An}_{51}$ & & & $\begin{array}{l}\text { Stöffler et al. } \\
(1986)\end{array}$ \\
\hline $\mathrm{An}_{50-57}$ & & & This work \\
\hline $\mathrm{An}_{63}$ & & & $\begin{array}{l}\text { Gibbons and } \\
\text { Ahrens (1977) }\end{array}$ \\
\hline $\mathrm{An}_{77}$ & & & Ostertag (1983) \\
\hline $\mathrm{An}_{79}$ & & & $\begin{array}{c}\text { Johnson and } \\
\text { Hörz (2003) }\end{array}$ \\
\hline $\mathrm{An}_{94}$ & & & This work \\
\hline $\mathrm{An}_{01}$ & 440 & Static & $\begin{array}{l}\text { Tomioka et al. } \\
\text { (2010) }\end{array}$ \\
\hline $\mathrm{An}_{01}$ & 540 & & $\begin{array}{l}\text { Tomioka et al. } \\
\text { (2010) }\end{array}$ \\
\hline $\mathrm{An}_{96}$ & 293 & & $\begin{array}{l}\text { Williams and } \\
\text { Jeanloz (1989) }\end{array}$ \\
\hline $\mathrm{An}_{100}$ & 293 & & $\begin{array}{l}\text { Daniel et al. } \\
\text { (1997) }\end{array}$ \\
\hline
\end{tabular}

Data for $\mathrm{An}_{52}$ plagioclase from in situ static pressure experiments (Kubo et al. 2010), and from shock experiments by Velde et al. (1989) and Kitamura et al. (1977) are not included here (see text).

Amorphization of Na-rich plagioclase $\left(\mathrm{An}_{01}\right)$ was observed in static pressure experiments conducted at pressures of $37 \mathrm{GPa}$ and temperatures of 293 and $440 \mathrm{~K}$ and at pressures of $31 \mathrm{GPa}$ and temperatures of $540 \mathrm{~K}$ (Fig. 7) (Tomioka et al. 2010). Tomioka et al. (2010) compared these static threshold pressures of 31$37 \mathrm{GPa}$ with the report of partly crystalline $\mathrm{An}_{01}$ plagioclase recovered from $50 \mathrm{GPa}$ shock experiments (Velde et al. 1989; Jaret et al. 2018). However, the results of Velde et al. (1989) and Jaret et al. (2018) are inconsistent with various shock recovery reports that observed complete amorphization of Na-rich plagioclase at much lower pressures (Fig. 7). For $\mathrm{An}_{01}$ and $\mathrm{An}_{19}$, completely amorphous maskelynite was recovered from shock experiments at 35 and $32 \mathrm{GPa}$, respectively (Heymann and Hörz 1990; Johnson and Hörz 2003). These shock pressures of 35 to $32 \mathrm{GPa}$ are identical to static pressures of 37 to $31 \mathrm{GPa}$ at which amorphous
Na-rich plagioclase was recovered from static experiments by Tomioka et al. (2010).

For Ca-rich plagioclase $\left(\mathrm{An}_{100}\right)$, amorphization pressures of $22 \mathrm{GPa}$ (Daniel et al. 1997) were reported from static experiments at room temperature using a sample from a low metamorphic rock from Val di Fassa, Monzoni, Italy (Van Tendeloo et al. 1989). These pressure and temperature values are similar to the amorphization of plagioclase $\left(\mathrm{An}_{94}\right)$ from the plutonic Grass Valley gabbro observed in $24 \mathrm{GPa}$ shock experiments conducted at room temperature in this work. For volcanic anorthite $\left(\mathrm{An}_{96}\right)$ from Miyake-zima, Izu Islands, Japan, the $22 \mathrm{GPa}$ static experiments produced partly isotropic plagioclase and higher pressures of $28 \mathrm{GPa}$ were required to produce fully isotropic maskelynite (Williams and Jeanloz 1989). Volcanic anorthite $\left(\mathrm{An}_{96}\right)$ of a scoria fall from the Fugoppe, Hokkaido, Japan, experimentally shocked to $30 \mathrm{GPa}$ displayed isotropic material including submicrometer thick lamellae of crystalline plagioclase, but still higher shock pressures were required to produce fully isotropic maskelynite (Kitamura et al. 1977). The apparent up to $6 \mathrm{GPa}$ differences in pressure required to produce fully isotropic maskelynite from plutonic and volcanic anorthite might reflect the influence of the degree of $\mathrm{Al} / \mathrm{Si}$ ordering. However, similar amorphization pressures are observed by comparing static and shock experiments for either plutonic or volcanic anorthite.

For an $\mathrm{An}_{52}$ plagioclase of intermediate chemical composition, the amorphization pressures were reported during in situ static experiments where the shocked sample is characterized inside the pressure cell (Kubo et al. 2010). It seems that Kubo et al. (2010) determined the amorphization pressure during compression, because the amorphization of $\mathrm{An}_{52}$ plagioclase occurred at $19 \mathrm{GPa}$ and at temperatures of $473 \mathrm{~K}$. For comparison, Daniel et al. (1997) report on static pressure experiments in which plagioclase $\left(\mathrm{An}_{96}\right)$ becomes amorphous at $16 \mathrm{GPa}$ during compression. However, Daniel et al. (1997) noted that higher pressures of $22 \mathrm{GPa}$ are required to produce material that remains amorphous after decompression. Clearly, a meaningful comparison of static and shock experiments requires that both samples are studied after decompression to ambient conditions. The in situ data from Kubo et al. (2010) are therefore not included in Fig. 7.

Considering that the time duration of static (h) and microsecond shock recovery experiments vary by nine orders of magnitude, the differences in amorphization pressures for plagioclase of less than $3 \mathrm{GPa}$ appear small. Hence, the results from microsecond shock recovery experiments can be directly applied to rocks exposed to shock pulse durations of milliseconds if not 


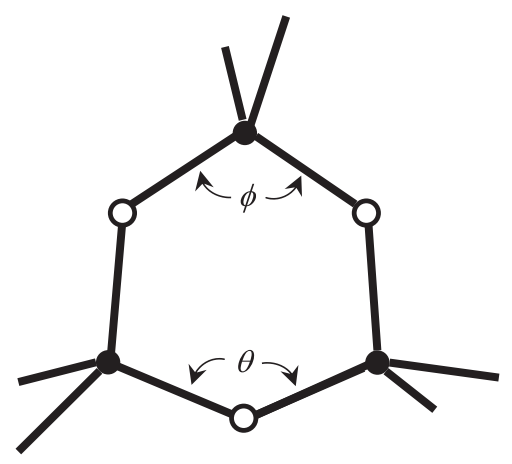

$$
\begin{aligned}
& 3 \text {-member tetrahedra } \\
& \theta=130.5^{\circ} \text { for } \phi=109.5^{\circ}
\end{aligned}
$$

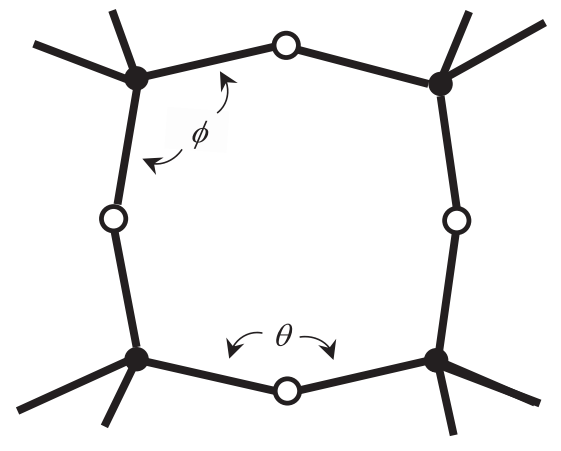

4-member tetrahedra

$\theta=160.5$ for $\phi=109.5^{\circ}$

Fig. 8. Schematic drawing showing (a) three- and (b) four-membered planar rings of tetrahedra. Solid dots $(\bullet)$ represent $\mathrm{T}=\mathrm{Al}$ or Si atoms and the open dots (O) represent $\mathrm{O}$ atoms. Values for the $\theta$ angle were calculated by Galeener (1982) by assuming that the O-T-O angle $(\Phi)$ is tetrahedral $\left(109.5^{\circ}\right)$. Redrawn after Galeener (1982). In the maskelynite spectra (Figs. 4, 5, and 7), the Raman bands between 400 and $600 \mathrm{~cm}^{-1}$ are attributed to the symmetric stretch of the oxygen atom along the line bisecting the T-O-T configuration $(\theta)$.

seconds during large-scale natural cratering events (Fritz et al. 2017).

Compared to shock and hydrostatic pressure experiments, the amorphization of plagioclase occurs at lower pressures in nonhydrostatic experiments (Daniel et al. 1997). A nonhydrostatic component, such as shearing along melt veins (Greshake et al. 2013), may explain the optical observations in several meteorites that isotropic maskelynite occurs locally near melt veins, yet the plagioclase remained birefringent elsewhere in these rocks (Binns 1967; Walton et al. 2016; Bischoff et al. 2019).

\section{Raman Spectral Properties}

Raman spectroscopy documents substantial changes in the organization of the $\mathrm{TO}_{4}(\mathrm{~T}=\mathrm{Si}, \mathrm{Al})$ tetrahedral units during the transformation of crystalline plagioclase to amorphous maskelynite (Heymann and Hörz 1990; Mernagh 1991; Reynard et al. 1999; Fritz et al. 2005b; Freeman et al. 2008). Raman spectra from unshocked plagioclase show strong bands in the 450 $600 \mathrm{~cm}^{-1}$ region that are related to the network of $\mathrm{TO}_{4}$ tetrahedra (Galeener 1982; Sharma et al. 1983; Matson et al. 1986; Mernagh 1991; Freeman et al. 2008). These tetrahedra form rings, and the number of ring members controls the bonding angle of bridging $\mathrm{O}$ atoms (Fig. 8). The motion of the oxygen atom along a line bisecting the T-O-T angle produces Raman bands in the spectral range of $480-600 \mathrm{~cm}^{-1}$. As the ring sizes decrease from four- to three-membered rings of tetrahedra, the Raman band positions increase from 400 to $600 \mathrm{~cm}^{-1}$. The variation of the $570 / 510 \mathrm{~cm}^{-1}$ band intensity ratio serves as a measure for the relative abundance of three- and four-membered rings of tetrahedra.

The increase in the $570 / 510 \mathrm{~cm}^{-1}$ band intensity ratio associated with the transformation of plagioclase into maskelynite implies an increase in three-membered rings of tetrahedra at the expense of four-membered rings (Figs. 4, 5, and 8) (Reynard et al. 1999; Fritz et al. 2005b). Further increase in the shock pressure produces maskelynite with a lower RI index accompanied by a shift of the ring statistics toward larger ring sizes (Figs. 1 and 4). Identical Raman spectra obtained for maskelynite $\left(\mathrm{An}_{50-57}\right)$ shocked to $45 \mathrm{GPa}$ and maskelynite shocked to $28 \mathrm{GPa}$ and then thermally annealed for 5 min to $1170 \mathrm{~K}$ (Fig. 6) show that these two approaches produce structurally similar material. The abundance of three-membered rings of tetrahedra (Fig. 6) increases with increasing An content, and this is likely related to the increasing $\mathrm{Al} / \mathrm{Si}$ ratio.

The shock-induced loss of crystallinity is gradual as documented by several Raman spectral properties. Due to shock deformation of plagioclase, the 480 and $510 \mathrm{~cm}^{-1}$ bands broaden, and narrow bands between 650 and $800 \mathrm{~cm}^{-1}$ and below $450 \mathrm{~cm}^{-1}$ disappear. The bands in the range of $900-1170 \mathrm{~cm}^{-1}$ are related to $\mathrm{T}-\mathrm{O}$ stretching vibrations of nonbridging $\mathrm{O}$ atoms attached to either Si or Al (Sharma et al. 1983; Matson et al. 1986). The absence of $950-1150 \mathrm{~cm}^{-1}$ bands in unshocked plagioclase can be explained by the lack of nonbridging O-atoms in a well-crystallized tectosilicate. Deformations and breaking of tetrahedral bonds during progressive amorphization lead to an increase in nonbridging $\mathrm{O}$ atoms attached to either $\mathrm{Si}$ or Al. Vibration of the nonbridging $\mathrm{Si}-\mathrm{O}$ and $\mathrm{Al}-\mathrm{O}$ units contributes to the broad hump at $900-1150 \mathrm{~cm}^{-1}$, and the shift of the maximum 
position allows us to discriminate maskelynite of different chemical composition and associated lattice order (Fig. 6).

On a microscopic scale, this reorganization of the tetrahedral bonds is expressed by the transition from highly fractured, shocked plagioclase where micrometersized fragments would still retain the plagioclase crystal structure to a rather coherent mass of isotropic maskelynite. Therefore, the lack of fractures in maskelynite is not evidence for a hot, molten stage during maskelynitization (Chen and El Goresy 2000; El Goresy et al. 2013), but instead is better explained by substantial reorganizations in the tetrahedral network.

\section{Solid State Formation of Diaplectic Glasses and Seifertite in the Shergotty Meteorite at Pressures of $30 \mathrm{GPa}$}

The thermal history during the transformation of plagioclase to maskelynite can be discussed using the pressure and temperature stability field of high pressure phases enclosed in maskelynite. In the Martian meteorite Shergotty (the maskelynite type specimen), maskelynite occasionally served as a shock pressure and temperature "container" for the formation of seifertite, a $\alpha-\mathrm{PbO}_{2}$ type $\mathrm{SiO}_{2}$ high pressure phase (Sharp et al. 1999; El Goresy et al. 2004). In a high temperature environment $(>1000 \mathrm{~K})$, seifertite is stable at pressures higher than the stability field of stishovite; i.e., depending on the temperature, it requires pressures in excess of 60-80 GPa (Sharp et al. 1999; Dubrovinsky et al. 2001; El Goresy et al. 2004). Lower temperatures inhibit the formation of stishovite, and seifertite can form from cristobalite at low temperatures ( $480 \mathrm{~K})$ and hydrostatic pressure of $25 \mathrm{GPa}$ (Bläß 2013; Kubo et al. 2015; Cernok et al. 2017). Thus, the presence of seifertite in maskelynite of the Shergotty meteorite is consistent with a low temperature formation at shock pressures of $30 \mathrm{GPa}$ as deduced from the shock effects in the rock-forming minerals, including maskelynite with a high RI (Stöffler et al. 1986; Fritz et al. 2005a).

\section{CONCLUSIONS}

New shock experiments on plagioclase together with literature data show that the minimum pressure to form maskelynite decreases from 33 to $\leq 24 \mathrm{GPa}$ along the albite to anorthite solid solution series, respectively. Shock recovery experiments at identical pressures and initial temperatures of 77 and $293 \mathrm{~K}$ produced maskelynite with identical optical properties in the present work. This is similar to the shock deformation of quartz, which resulted in identical optical properties at given shock pressure and initial temperatures of 77 and

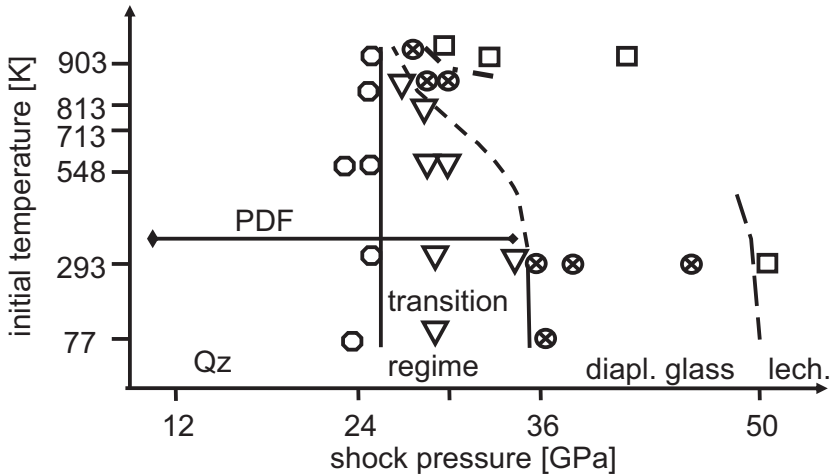

Fig. 9. Observed shock effects for target quartz of different initial temperature as a function of shock pressure. PDF = planar deformation feature; $\bigcirc=$ quartz; $\nabla=$ quartz with reduced density, birefringence, and refractive index; $\boldsymbol{0}$ = diaplectic glass; $\square=$ lechatelierite. Redrawn after Fritz et al. (2011).

$548 \mathrm{~K}$ (Fritz et al. 2011) (Fig. 9). Both results show that the formation of diaplectic glass is controlled by pressure, and it is rather independent of temperatures in the low temperature region-i.e., $<540 \mathrm{~K}$ as inferred from the static pressure experiments by Tomioka et al. (2010). In addition, amorphization of plagioclase occurs at similar pressures $(< \pm 3 \mathrm{GPa})$ in shock and static experiments as long as these experiments are conducted at the same temperatures, and the materials are characterized after decompression to atmospheric pressures. For quartz, fully amorphous material was recovered from static experiments at $293 \mathrm{~K}$ and pressures $>30 \mathrm{GPa}$ (Kingma et al. 1993) and from $34 \mathrm{GPa}$ shock experiments at initial temperatures of 293 K (Stöffler and Langenhorst 1994). Microsecond shock recovery experiments on plagioclase and quartz produce the same materials as those recovered from static experiments at identical pressures and temperatures. This advocates that the properties of plagioclase, quartz, or cristobalite (see previous paragraph on seifertite) during shock compression can be studied using in situ observations of materials exposed to hydrostatic pressures at relevant temperatures.

It is established that the shock metamorphic effects of rock-forming minerals such as quartz, plagioclase, olivine, and pyroxene calibrated by shock recovery experiments can serve as a reliable and meaningful thermobarometer for the shock conditions in naturally shocked nonporous rocks (see also Fritz et al. 2017). It is notable that the minimum shock pressure for maskelynitization decreases with increasing An content, and thus is different for specific types of meteorites (Fig. 7).

For example in Martian meteorites, the shock pressure and temperature conditions (Fritz et al. 2005a, 
2005b) were found to be highly consistent with a thermal history inferred from a variety of independent properties, including (1) the radiogenic ${ }^{4} \mathrm{He}$ inventory (Schwenzer et al. 2008), (2) the magnetic properties of ALH84001 (Weiss et al. 2000); (3) the recrystallization of plagioclase in a decimeter-sized rock that cooled in space (Fritz et al. 2005a), (4) the formation of seifertite enclosed in maskelynite in the Shergotty meteorite (Sharp et al. 1999; Bläß 2013; Kubo et al. 2015; Cernok et al. 2017; this work), and (5) the formation and preservation of thermally unstable high pressure phases associated with shock-produced melt veins and pockets in some meteorites (Fritz et al. 2017; Tomioka and Miyahara 2017; Bischoff et al. 2019). The low temperature solid state formation of maskelynite does not reset the ${ }^{40} \mathrm{Ar}-{ }^{39} \mathrm{Ar}$ chronometer of rocks, as $\mathrm{Ar}$ diffusion requires a prolonged heating regime (Jessberger and Ostertag 1982; Fernandes et al. 2009; Shuster et al. 2010).

The formation of diaplectic glasses was compared with solid state or subsolidus transformations (Jaret et al. 2015) such as vitrification via an amorphous, highly coordinated structure during compression to a decompressed glass (Williams and Jeanloz 1989), via an increase in lattice defects similar to vitrification by radiation damage (Ashworth and Schneider 1985), or due to a gradual collapse of the lattice into domains that are eventually so small that they are beyond coherent X-ray diffraction of some $1-20 \mathrm{~nm}$ in size (Hörz and Quaide 1973). Due to their density and amorphous structure, the diaplectic glasses are often described as dense glasses. However, since they derive from a crystalline precursor due to pressure-induced collapse of the crystal lattice, these diaplectic glasses could better be viewed as inflated or shattered crystals, i.e., the term diaplectic (to destroy by striking) correctly describes the formation process.

Acknowledgments - Shock experiments were conducted during the research in the frame of the Helmholtz Alliance on Planetary Evolution and Life - WP3200. The sample disks and ARMCO container were prepared at the MfN by H.-R. Knöfler and H. Schneider. The gabbro was given to us by $\mathrm{K}$. Ross and kindly provided by R. Wenk and B. Cassata (University of California at Berkeley). We thank Prof. Doug Crowe for providing rock sample B59-36-A from the Gilles O. Allard Economic Geology Collection, Athens, GA. Financial support for V. A. F. through the D. F. G. research grant FE 1523/3-1 and a Marie Skłodowska Curie Fellow, funded by the European Commission, HORIZON2020 Programme, grant number 749815 are acknowledged. We highly appreciate the detailed and constructive review by Fred Hörz and the Associate
Editor Gordon Osinski, who greatly helped to improve a previous version of this manuscript.

\section{Editorial Handling-Dr. Gordon Osinski}

\section{REFERENCES}

Arndt J., Hummel W., and Gonzalez-Cabeza I. 1982. Diaplectic labradorite glass from the Manicouagan impact crater. Physics and Chemistry of Minerals 8:230-239. https://doi.org/10.1007/BF00309482

Ashworth J. R. and Schneider H. 1985. Deformation and transformation in experimentally shock-loaded quartz. Physics and Chemistry of Minerals 11:241-249.

Binns R. A. 1967. Stony meteorites bearing maskelynite. Nature 213:1111-1112.

Bischoff A., Schleiting M., and Patzek M. 2019. Shock stage distribution of 2280 ordinary chondrites - Can bulk chondrites with a shock stage of S6 exist as individual rocks? Meteoritics \& Planetary Science. https://doi.org/10. $1111 /$ maps. 13208

Bläß U. W. 2013. Shock-induced formation mechanism of seifertite in shergottites. Physics of Chemistry and Minerals 40:425-437.

Bunch T. E., Cohen A. J., and Dence M. R. 1967. Natural terrestrial maskelynite. The American Mineralogist 52:244253.

Cernok A., Marquardt K., Caracas R., Bykova E., Habler G., Liermann H.-P., Hanfland M., Mezouar M., Bobocioiu E., and Dubrovinsky L. 2017. Compressional pathways of $\alpha$ cristobalite, structure of cristobalite X-I, and towards the understanding of seifertite formation. Nature Communications 8:15647.

Chen M. and El Goresy A. 2000. The nature of maskelynite in shocked meteorites: Not diaplectic glass but a glass quenched from shock-induced dense melt at high pressures. Earth and Planetary Science Letters 179:489-502.

Daniel I., Gillet P., McMillan P. F., Wolf G., and Verhelst M. A. 1997. High-pressure behavior of anorthite: Compression and amorphization. Journal of Geophysical Research: Solid Earth 102:10,313-10,325.

Dubrovinsky L. S., Dubrovinskaia N. A., Saxena S. K., Tutti F., Rekhi S., Le Bihan T., Shen G., and Hu J. 2001. Pressure-induced transformations of cristobalite. Chemical Physics Letters 333:264-270.

Duke M. 1968. The Shergotty meteorite: Magmatic and shock metamorphic features. In Shock metamorphism of natural materials, edited by French B. M. and Short N.M. Baltimore, Maryland: Mono Book Corp. pp. 613-621.

El Goresy A., Dubrovinsky L., Sharp T. G., and Chen M. 2004. Stishovite and post-stishovite polymorphs of silica in the shergotty meteorite: Their nature, petrographic settings versus theoretical predictions and relevance to Earth's mantle. Journal of Physics and Chemistry of Solids 65:1597-1608.

El Goresy A., Gillet P., Miyahara M., Ohtani E., Ozawa S., Beck P., and Montagnac G. 2013. Shock-induced deformation of Shergottites: Shock-pressures and perturbations of magmatic ages on Mars. Geochimica et Cosmochimica Acta 101:233262.

Engelhardt W. von, Arndt J., Stöffler D., Müller W. F., Jeziorkowski H., and Gubser R. A. 1967. Diaplektische Gläser in den Breccien des Ries von Nördlingen als 
Anzeichen für Stoßwellenmetamorphose. Contributions to Mineralogy and Petrology 15:93-102.

Engelhardt W. von, Arndt J., Müller W. F., and Stöffler D. 1970. Shock metamorphism of lunar rocks and origin of the regolith at the Apollo 11 landing site. Geochimica et Cosmochimica Acta Supplement 1:363.

Fernandes V. A., Burgess R., and Morris A. 2009. ${ }^{40} \mathrm{Ar}-{ }^{39} \mathrm{Ar}$ age determinations of lunar basalt meteorites Asuka 881757, Yamato 793169, Miller Range 05035, LaPaz Icefield 02205, Northwest Africa 479, and basaltic breccia Elephant Moraine 96008. Meteoritics \& Planetary Science 44:805-821.

Freeman J. J., Wang A., Kuebler K. E., Jolliff B. L., and Haskin L. A. 2008. Characterization of natural feldspars by Raman spectroscopy for future planetary exploration. The Canadian Mineralogist 46:1477-1500.

Fritz J., Greshake A., Hecht L., and Stöffler D. 2002. Shock metamorphism of Martian meteorites: New data from quantitative shock barometry (abstract \#1504). 33th Lunar and Planetary Science Conference. CD ROM.

Fritz J., Artemieva N. A., and Greshake A. 2005a. Ejection of Martian meteorites. Meteoritics \& Planetary Science 40:1393-1411.

Fritz J., Greshake A., and Stöffler D. 2005b. Micro-Raman spectroscopy of plagioclase and maskelynite in Martian meteorites: Evidence of progressive shock metamorphism. Antarctic Meteorite Research 18:96-116.

Fritz J., Wünnemann K., Reimold W. U., Meyer C., and Hornemann U. 2011. Shock experiments on quartz targets pre-cooled to $77 \mathrm{~K}$. International Journal of Impact Engineering 38:440-445.

Fritz J., Greshake A., and Fernandes V. A. 2017. Revising the shock classification of meteorites. Meteoritics \& Planetary Science 52:1216-1232.

Galeener F. L. 1982. Planar rings in vitreous silica. Journal of Non-Crystalline Solids 49:53-62.

Gibbons R. W. and Ahrens T. J. 1977. Effects of shock pressure on plagioclase. Physics and Chemistry of Minerals 1:95-107.

Gillet P., El Goresy A., Beck P., and Chen M. 2007. Highpressure mineral assemblages in shocked meteorites and shocked terrestrial rocks: Mechanisms of phase transformations and constraints to pressure and temperature histories. In Advances in high-pressure mineralogy, edited by Ohtani E. Geological Society of America Special Paper 421:57-82.

Grady D. E. 1980. Shock deformation of brittle solids. Journal of Geophysical Research 85:913-924.

Greshake A., Fritz J., Böttger U., and Goran D. 2013. Shear induced ringwoodite formation in the Martian shergottite Dar al Gani 670. Earth and Planetary Science Letters 375:383-394.

Hemley R. J., Jephcoat A. P., Mao H. K., Ming L. C., and Manghnan M. H. 1988. Pressure-induced amorphization of crystalline silica. Nature 334:52-54.

Heymann D. and Hörz F. 1990. Raman-spectroscopy and Xray diffractometer studies of experimentally produced diaplectic feldspar glass. Physics and Chemistry of Minerals 17:38-44.

Hörz F. and Quaide W. L. 1973. Debye-Scherrer investigations of experimentally shocked silicates. The Moon 6:45-82.

Jaret S. J., Woerner W. R., Phillips B. L., Ehm L., Nekvasil H., Wright S. P., and Glotch T. D. 2015. Maskelynite formation via solid-state transformation: Evidence of infrared and X-ray anisotropy. The Journal of Geophysical Research Planets 120:570-587.

Jaret S. T., Johnson J. R., Sims M., Di Francesco N., and Glotch T. 2018. Microspectroscopic and petrographic comparison of experimentally shocked albite, andesine, and bytownite. Journal of Geophysical Research 123:17011722. https://doi.org/10.1029/2018JE005523

Jarosewich E., Nelen J. A., and Norberg J. A. 1980. Reference samples for electron microprobe analysis. Geostandard Newsletters 4:43-47.

Jessberger E. K. and Ostertag R. 1982. Shock-effects on the $\mathrm{K}-\mathrm{Ar}$ system of plagioclase feldspar and the age of anorthosite inclusions from North-Eastern Minnesota. Geochimica et Cosmochimica Acta 46:1465-1471.

Johnson J. R. 2012. Thermal infrared spectra of experimentally shocked andesine anorthosite. Icarus 221:359-364.

Johnson J. R. and Hörz F. 2003. Visible/near-infrared spectra of experimentally shocked plagioclase feldspars. Journal of Geophysical Research (Planets) 108k: 6-1.

Kingma K. J., Meade C., Hemley R. J., Mao H. K., and Veblen D. R. 1993. Microstructural observations of alphaquartz amorphization. Science 259:666-669.

Kitamura M., Goto T., and Syono Y. 1977. Intergrowth textures of diaplectic glass and crystal in shock-loaded Panorthite. Contributions to Mineralogy and Petrology 61:299-304.

Kovach H. A. and Jones R. H. 2010. Feldspar in type 4-6 ordinary chondrites: Metamorphic processing on the $\mathrm{H}$ and LL chondrite parent bodies. Meteoritics \& Planetary Science 45:246-264.

Kubo T., Kimura M., Kato T., Nishi M., Tominaga A., Kikegawa T., and Funakoshi K.-I. 2010. Plagioclase breakdown as an indicator for shock conditions of meteorites. Nature Geoscience 3:41-45.

Kubo T., Kato T., Higo Y., and Funakoshi K.-I. 2015. Curious kinetic behavior in silica polymorphs solves seifertite puzzle in shocked meteorite. Science Advances 1: e1500075.

Langenhorst F. 1994. Shock experiments on pre-heated [alpha]and [beta]-quartz: II. X-ray and TEM investigations. Earth and Planetary Science Letters 128:683-698.

Matson D. W., Sharma K. S., and Philpotts J. A. 1986. Raman spectra of some tecto silicates and of glasses along the orthoclase-anorthite and nepheline-anorthite joins. American Mineralogist 71:694-704.

Mayne R. G., McSween H. Y. Jr., McCoy T. J., and Gale A. 2009. Petrology of the unbrecciated eucrites. Geochimica et Cosmochimica Acta 73:794-819.

Mernagh T. P. 1991. Use of the laser Raman microprobe for discrimination amongst feldspar minerals. Journal of Raman Spectroscopy 22:453-457.

Meyer C., Fritz J., Misgaiski M., Stöffler D., Artemieva N. A., Hornemann U., Moeller R., De Vera J.-P., Cockell C., Horneck G., Ott S., and Rabbow E. 2011. Shock experiments in support of the Lithopanspermia theory: The influence of host rock composition, temperature, and shock pressure on the survival rate of endolithic and epilithic microorganisms. Meteoritics \& Planetary Science 46:701-718.

Milton D. J. and De Carli P. S. 1963. Maskelynite: Formation by explosive shock. Science 140:670-671.

Müller W. F. and Hornemann U. 1969. Shock-induced planar deformation structures in experimentally shock-loaded olivines and in olivines from chondritic meteorites. Earth and Planetary Science Letters 7:251-264. 
Osinski G. R., Grieve R. A. F., Bleacher J. E., Neish C. D., Pilles E. A., and Tornabene L. L. 2018. Igneous rocks formed by hypervelocity impact. Journal of Volcanological and Geothermal Research 353:25-54.

Ostertag R. 1983. Shock experiments on feldspar crystals. Proceedings, 14th Lunar and Planetary Science Conference. Journal of Geophysical Research, Supplement 88:B365-B367.

Ostertag R. and Stöffler D. 1982. Thermal annealing of experimentally shocked feldspar crystals. Journal of Geophysical Research 87(S01):A457-A463.

Reynard B., Okuno M., Shimada Y., Syono Y., and Willaime C. 1999. A Raman spectroscopic study of shock-wave densification of anorthite (CaAl2Si2O 8) glass. Physics and Chemistry of Minerals 26:432-436.

Schwenzer S. P., Fritz J., Stöffler D., Trieloff M., Amini M., Greshake A., Herrmann S., Herwig K., Jochum K. P., Mohapatra R. K., Stoll B., and Ott U. 2008. Helium loss from Martian meteorites mainly induced by shock metamorphism: Evidence from new data and a literature compilation. Meteoritics \& Planetary Science 43:1841-1859.

Sharma S. K., Simons B., and Yoder H. S. 1983. Raman study of anorthite, calcium Tschermak's pyroxene, and gehlenite in crystalline and glassy states. American Mineralogist 68:1113-1125.

Sharp T. G. and de Carli P. S. 2006. Shock effects in meteorites. In Meteorites and the Early Solar System II, edited by Lauretta D. S. and McSween Jr. H.Y. Tucson, Arizona: University of Arizona Press.

Sharp T. G., El Goresy A., Wopenka B., and Chen M. 1999. A post-stishovite $\mathrm{SiO}_{2}$ polymorph in the meteorite Shergotty: Implications for impact events. Science 284:1511.

Shuster D. L., Balco G., Cassata W. S., Fernandes V. A., Garrick-Bethell I., and Weiss B. P. 2010. A record of impacts preserved in the lunar regolith. Earth and Planetary Science Letters 290:155-165.

Stöffler D. and Langenhorst F. 1994. Shock metamorphism of quartz in nature and experiment: I Basic observation and theory. Meteoritics 29:155-188.

Stöffler D., Ostertag R., Jammes C., Pfannschmidt G., Sen Gupta P. R., Simon S. B., Papike J. J., and Beauchamp R. H. 1986. Shock metamorphism and petrography of the Shergotty achondrite. Geochimica et Cosmochimica Acta 50:889-903.
Tomioka N. and Miyahara M. 2017. High-pressure minerals in shocked meteorites. Meteoritics and Planetary Science 52:2017-2039.

Tomioka N., Kondo H., Kunikata A., and Nagai T. 2010. Pressure-induced amorphization of albitic plagioclase in an externally heated diamond anvil cell. Geophysical Research Letters 37:L21301.

Tröger W. E. 1982. Optische Bestimmung der gesteinsbildenden Minerale. Teil 1 Bestimmungstabellen. Stuttgart, Germany: Schweizerbart. 188 p.

Tschermark G. 1872. Die Meteoriten von Shergotty und Gopalpur. Wien: Sitzungsbericht der Kaiserlichen Akademie der Wissenschaften 65:122-145.

Tschermark G. 1883. Beitrag zur Klassifikation der Meteoriten. Wien: Sitzungsbericht der Kaiserlichen Akademie der Wissenschaften 88:347-371.

Van Tendeloo G., Ghose S., and Amelinckx S. 1989. A dynamical model for the PI- li phase transition in anorthite, $\mathrm{CaAl}_{2} \mathrm{Si}_{2} \mathrm{O}_{8}$ I. Evidence from electron microscopy. Physics and Chemistry of Minerals 16:311-319.

Velde B., Syono Y., Kikuchi M., and Boyer H. 1989. Raman microprobe study of synthetic diaplectic plagioclase feldspars. Physics and Chemistry of Minerals 16:436-441.

Walton E. T., Tschanuer O., Herd C. D. K., and Agee C. B. 2016. Shock effects in new Martian olivine basalt Northwest Africa 10416: Distinct from shergottites but Northwest Africa 8159 (abstract \#1639). 47th Lunar and Planetary Science Conference. CD ROM.

Weiss B. P., Kirschvink J. L., Baudenbacher F. J., Vali H., Peters N. T., Macdonald F. A., and Wikswo J. P. 2000. A low temperature transfer of ALH84001 from Mars to Earth. Science 290:791-795.

Wieczorek M. A., Jolliff B. L., Khan A., Pritchard M. E., Weiss B. P., Williams J. G., Hood L. L., Righter K., Neal C. R., Shearer C. K., McCallum I. S., Tompkins S., Hawke B. R., Peterson C., Gillis J. J., and Bussey B. 2006. The constitution and structure of the lunar interior. In New views of the Moon, edited by Jolliff B., Wieczorek M. A., Shearer C. K. and Neal C. R. Washington, D.C.: Mineralogical Society of America. pp. 222-364.

Williams Q. and Jeanloz R. 1989. Static amorphization of anorthite at $300 \mathrm{~K}$ and comparison with diaplectic glass. Nature 338:413-415. 